\title{
Effects of vigabatrin, carbamazepine or its combination on the pituitary- gonadal axis in male Wistar rats
}

\author{
Akinsomisoye O.S. ${ }^{1}$, Owolabi A.R. ${ }^{2}$, Adeyeye O.B. ${ }^{1,3},{ }^{*}$ Osuntokun O.S. ${ }^{1,4}$, Akintayo C.O. ${ }^{5}$ \\ and Oladele A. ${ }^{6}$
}

\begin{abstract}
Objectives: Epilepsy is the most common non-infectious neurologic disease in developing African countries following stroke and Alzheimer's disease. Most conventional antiepileptic drugs, due to their centrally acting potentials have been implicated in the deregulation of reproductive hormones. This study assessed the effect of the single and combined administration of vigabatrin (VIG) and carbamazepine (CBZ) on the pituitary-gonadal axis of male Wistar rats.
\end{abstract}

Methods: Fifty male Wistar rats were randomly divided into 5 groups $(n=10)$. The animals were administered with distilled water ( $0.1 \mathrm{ml} / \mathrm{kg} /$ day), VIG $(200 \mathrm{mg} / \mathrm{kg} /$ day $)$, CBZ (200 mg/kg/day), VIGCBZ combination $(100 \mathrm{mg} / \mathrm{kg} /$ day each) and VIG-CBZ combination $(200 \mathrm{mg} / \mathrm{kg} /$ day each) for 8 weeks. Twenty-four hours after the last dose, 5 rats from each group were sacrificed, while the remaining 5 eventually sacrificed after another 8 week of drug withdrawal. The level of luteinizing hormone, follicle stimulating hormone and testosterone were determined from the serum. The weight of the reproductive organs and sperm indices were assayed, while the testicular tissue were examined for signs of histological alteration.

Results: The results showed significant decrease in the levels of luteinizing hormone, follicle stimulating hormone, testosterone and sperm physiological indices. Morphological alteration was noticed in the testes of all the treated rats. However, there was restoration of these parameters sequelae to 8 weeks cessation of treatment.

Conclusion: Single and combined administration of VIG and CBZ resulted into pituitary-gonadal axis hormonal deregulation and alterations in the sperm profile which were however reversible upon cessation of treatment.

Key words: epilepsy, vigabatrin, carbamazepine, sperm, testosterone

*Correspondence author

Osuntokun O.S.

http://orcid.org/0000-0002-1080-7946

Email: opeyemi.osuntokun@uniosun.edu.ng

${ }^{1}$ Department of Physiological Sciences, Obafemi Awolowo University, Ile-Ife, Nigeria

${ }^{2}$ Department of Medical Pharmacology and Therapeutics, Obafemi Awolowo University, Ile-Ife, Ibadan, Nigeria

${ }^{3}$ Department of Basic Medical Sciences, Achievers University, Owo, Nigeria

${ }^{4}$ Department of Physiology, College of Health Sciences, Osun State University, Osogbo, Nigeria

${ }^{5}$ Department of Physiology, College of Medicine and Health Sciences, Afe Babalola University, Ado-Ekiti, Nigeria

${ }^{6}$ Department of Morbid Anatomy, Obafemi Awolowo University Teaching Hospital Complex, Ile-Ife, Nigeria

Research Journal of Health Sciences subscribed to terms and conditions of Open Access publication. Articles are distributed under the terms of Creative Commons Licence (CC BY-NC-ND 4.0). (http://creativecommons.org/licences/by-nc-nd/4.0).

http://dx.doi.org/10.4314/rejhs.v5i4.3 


\title{
Effets de la vigabatrine, de la carbamazépine ou de sa combinaison sur l'axe hypophyso-gonadique chez des rats Wistar mâles
}

\author{
Akinsomisoye O.S. ${ }^{1}$, Owolabi A.R. ${ }^{2}$, Adeyeye O.B. ${ }^{1,3}$, ${ }^{*}$ Osuntokun O.S. ${ }^{1,4}$, Akintayo C.O. ${ }^{5}$ \\ and Oladele A.
}

\section{Resume}

Objectif: L'épilepsie est la maladie neurologique non infectieuse la plus fréquente dans les pays africains en développement après un $\mathrm{AVC}$ et la maladie d'Alzheimer. La plupart des médicaments antiépileptiques conventionnels, en raison de leurs potentiels d'action centraux, ont été impliqués dans la dérégulation des hormones de la reproduction. Cette étude a évalué l'effet de l'administration unique et combinée de vigabatrine (VIG) et de carbamazépine (CBZ) sur l'axe hypophyso-gonadique de rats mâles Wistar.

Méthodes: Cinquante rats Wistar mâles ont été divisés au hasard en 5 groupes $(\mathrm{n}=10)$. Les animaux ont été administrés avec de l'eau distillée ( $0,1 \mathrm{ml} / \mathrm{kg} /$ jour), VIG (200 mg / kg / jour), CBZ (200 mg / $\mathrm{kg} /$ jour), combinaison VIG-CBZ (100 mg / kg / jour chacun) et Combinaison VIG-CBZ (200 mg / $\mathrm{kg} /$ jour chacun) pendant 8 semaines. Vingt-quatre heures après la dose perdue, 5 rats de chaque groupe ont été sacrifiés, tandis que les 5 restants ont finalement été sacrifiés après 8 semaines de retrait de médicament. Le niveau d'hormone lutéinisante, la testostérone, hormone folliculo-stimulante et le glutathion réduit ont été déterminés à partir du sérum, le poids des organes reproducteurs et les indices de sperme ont été testés, tandis que le tissu testiculaire a été examiné pour toute altération histologique.

Résultats: Les résultats ont montré une diminution significative des taux d'hormone lutéinisante, d'hormone folliculo-stimulante, de testostérone, de paramètres du sperme et de glutathion. Une altération histologique a été observée dans les testicules de tous les rats traités. Cependant, il y avait une restauration de ces paramètres séquelles à 8 semaines d'arrêt du traitement.

Conclusion: L'administration unique et combinée de VIG et de CBZ a entraîné des modifications physiopathologiques du profil hormonal de l'axe hypophyso-gonadique et une diminution du marqueur antioxydant qui était cependant réversible à l'arrêt de l'administration du médicament.

Mots-clés: épilepsie, vigabatrine, carbamazépine, sperme, testostérone

*Correspondance auteur

Osuntokun O.S.

http://orcid.org/0000-0002-1080-7946

Email: opeyemi.osuntokun@uniosun.edu.ng

\footnotetext{
${ }^{1}$ Department of Physiological Sciences, Obafemi Awolowo University, Ile-Ife, Nigeria

${ }^{2}$ Department of Medical Pharmacology and Therapeutics, Obafemi Awolowo University, Ile-Ife, Ibadan, Nigeria

${ }^{3}$ Department of Basic Medical Sciences, Achievers University, Owo, Nigeria

${ }^{4}$ Department of Physiology, College of Health Sciences, Osun State University, Osogbo, Nigeria

${ }^{5}$ Department of Physiology, College of Medicine and Health Sciences, Afe Babalola University, Ado-Ekiti, Nigeria

${ }^{6}$ Department of Morbid Anatomy, Obafemi Awolowo University Teaching Hospital Complex, Ile-Ife, Nigeria
} 


\section{INTRODUCTION}

Epilepsy is the most common noninfectious neurologic disease following stroke and Alzheimer's disease (1). It occurs in about $1 \%$ of people worldwide (65 million)(2) with nearly $80 \%$ of cases occurring in developing countries (3) including Nigeria (1) and it remains a major medical and social problem (2). Epilepsy cannot be cured, but seizures are controllable with medication in about $70 \%$ of cases (4). About 5-10 $\%$ of all people will have an unprovoked seizure (5) by the age of 80 , and the chance of experiencing a second seizure is between 40 and $50 \%$ (6). The highest incidence of new cases occurs among children less than 5 years $(50-100$ cases $/ 100,000)$ and adults greater than 65 years of age (70-150 cases/100,000) (7). These seizures are episodes that can vary from brief and nearly undetectable to long periods of vigorous shaking (8). However, a lot of antiepileptic drugs are used in the treatment and management of seizures. These drugs include pregabalin, zonisamide, CBZ, VIG, phenytoin, sodium valproate, gabapentin (9) to mention but a few. Monotherapy treatment of epilepsy is very common and a good choice especially for newly diagnosed epilepsy. However a combination of two antiepileptic drugs is usually considered when there is failure or lack of efficacy of the monotherapy regimens (10).

Today, the roles of epilepsy and antiepileptic medication in contributing to reproductive endocrine disorders in people with epilepsy are still widely debated. Epilepsy itself may disturb the regulation of secretion of reproductive hormones (11) while on the other hand, antiepileptic drugs (AEDs) have also been shown to induce reproductive endocrine disorders (12). Mono-therapeutic treatment of epilepsy using a conventional antiepileptic drug carbamazepine has been reported to have prominent adverse effects especially on testicular functions (13). Vigabatrin is a newer antiepileptic which is used as an adjunct therapy in the treatment of epilepsy (14). However, reports on the combination of these drugs on reproductive functions have not been reported and need to be investigated, hence this study.

\section{MATERIALS AND METHODS}

Fifty adult male Wistar strain rats weighing $120 \mathrm{~g}$ - $150 \mathrm{~g}$ were used for this study. They were obtained from the Animal House of the College of Health Sciences, Obafemi Awolowo University, Ile-Ife and were housed in separate cages. The animals were kept under normal environmental conditions and had free access to standard rodent pellet diet (Caps Feed Plc Osogbo, Nigeria) and water ad libitum. They were allowed to acclimatize in the laboratory for 2 weeks before the commencement of the study. The experimental procedures adopted in this study were in strict compliance with Experimental Animal Care and Use of Laboratory Animals in Biomedical Research, College of Health Sciences, Obafemi Awolowo University, Ile-Ife. The animals were randomly divided into 5 groups, each consisted of 10 animals except the control group of 5 rats.

Vigabatrin (VIG) and carbamazepine (CBZ) obtained from Novartis, Switzerland were used for this study. Vigabatrin is water-soluble; therefore, it was dissolved in distilled water. Five hundred milligrams (500mg) of VIG was dissolved in $5 \mathrm{ml}$ of distilled water. CBZ is not water-soluble, therefore, tween 80 was used to dissolve carbamazepine. Two hundred milligrams $(200 \mathrm{mg})$ of carbamazepine was dissolved in $1 \mathrm{ml}$ of tween 80 and calculated amounts were administered to the rats orally.

Group 1 which was the control group received distilled water $(0.1 \mathrm{ml})$ orally for 8 weeks; Group 2 received $200 \mathrm{mg} / \mathrm{kg} /$ day of VIG orally for 8 weeks (15). Group 3 received $200 \mathrm{mg} / \mathrm{kg} /$ day of carbamazepine orally for 8 weeks (16). Group 4 was given $100 \mathrm{mg} / \mathrm{kg} /$ day of VIG in combination with $100 \mathrm{mg} / \mathrm{kg} /$ day of carbamazepine orally for 8 weeks. Group 5 received VIG $(200 \mathrm{mg} / \mathrm{kg} /$ day $)$ in combination with CBZ (200mg/kg/day) orally for 8 weeks.

Twenty- four hours after the last drug administration, 5 rats from groups 1-5 (were picked at random) were sacrificed through cervical dislocation. Blood samples were collected via cardiac puncture and were centrifuged for 15 minutes at 4000rpm using cold centrifuge $\left(4^{\circ} \mathrm{C}\right)$ to obtain serum which was used for hormonal assays. Sperm characteristics (sperm count, viability, motility and morphology) were also evaluated using conventional methodology. The remaining rats in Groups 1-5 were allowed to recover from the effects of the drug(s) for a period of 8 weeks and sacrificed 24 hours after the lapse of 8 weeks of recovery period, afterwards the assessment of the aforementioned parameters were also carried out.

The effects of the administered drugs on the body weight of the rats was determined at $24^{\text {th }}$ hour after the last dose, just before the sacrifice with sensitive digital weighing balance (Camry, China). Rats were dissected and the reproductive tract was taken out trimmed free of fat and the 
following organs: epididymis and testes were removed and weighed separately on a sensitive electronic weighing balance. The testes were fixed in $10 \%$ formol saline for further histological studies.

Sperm counts were assessed immediately the rats were sacrificed using a counting chamber as earlier described by Raji et al. (17), where the total number of sperm in the ejaculate $=$ The concentration of sperm per $\mathrm{ml} \mathrm{X}$ the total number of $\mathrm{ml}$ of raw semen. The results were expressed as million/ml suspension.

Epididymal sperm motility was assessed immediately the rats were sacrificed. Sperm progressive motility was determined according to the procedure reported by Otoom et al. (18). The number of motile spermatozoa were calculated per unit area and expressed as percentage motility.

Viability study was done as described by Maree $e t$ al. (19). Morphological aberrations of abnormal spermatozoa were determined from a total count of 400 spermatozoa in smears obtained with Eosin and Nigrosin stain.

Serum testosterone concentration was determined using the enzyme-linked immunosorbent assay (ELISA) via the use of ELISA kit (MonobindInc, Lake Forest, CA 92630, USA) as described by the manufacturer's instruction.

Testicular histology was carried out according to Raji, et al. (20). The testes were fixed in $10 \%$ formol saline immediately after weighing. The preserved testes were then passed through the routine laboratory histological procedures and slides were stained with haematoxylin and eosin. Sections were viewed under the microscope with photomicrograph taken with a Leica DM750 camera microscope.

Data collected were analysed using descriptive and inferential statistics. The control and test groups were compared using t-test, ANOVA and Student-Newman-Keuls post hoc analysis where appropriate using GraphPad Prism 5.03 (GraphPad Software Inc., CA, USA) as the statistical analysis package. The results were presented as mean \pm SEM in graphs and tables and the level of significance was taken as p-value $<0.05$.

\section{RESULTS}

In this study, VIG $(200 \mathrm{mg} / \mathrm{kg})$ significantly $(\mathrm{p}<0.05)$ decreased the body weight of the treated rats compared to the control group. Although these animals were unable to fully recover after 56 days of drug withdrawal but there was a significant $(\mathrm{p}<0.05)$ increase in the percentage weight gain (Table 1)

Eight weeks of VIG $(200 \mathrm{mg} / \mathrm{kg})$ treatment significantly $(\mathrm{p}<0.05)$ increased the epididymal weight while CBZ $(200 \mathrm{mg} / \mathrm{kg})$ significantly $(p<0.05)$ decreased it (Figure 1). There was no significant difference $(p<0.05)$ in the weight of epididymis after VIG (100mg/kg) + CBZ $(100 \mathrm{mg} / \mathrm{kg})$ combination treatment compared to the control while VIG $(200 \mathrm{mg} / \mathrm{kg})+\mathrm{CBZ}$ $(200 \mathrm{mg} / \mathrm{kg})$ significantly $(\mathrm{p}<0.05)$ increased epididymal weight.

In Figure 2, the relative testicular weight of VIG $(200 \mathrm{mg} / \mathrm{kg})$, VIG $(100 \mathrm{mg} / \mathrm{kg})+\mathrm{CBZ}$ $(100 \mathrm{mg} / \mathrm{kg})$ and VIG $(200 \mathrm{mg} / \mathrm{kg})+\mathrm{CBZ}$ $(200 \mathrm{mg} / \mathrm{kg})$ combination treated rats significantly $(\mathrm{P}<0.05)$ increased but decreased in CBZ $(200 \mathrm{mg} / \mathrm{kg})$ compared to control.

In the study, VIG $(200 \mathrm{mg} / \mathrm{kg}), \mathrm{CBZ}$ $(200 \mathrm{mg} / \mathrm{kg}), \quad \mathrm{VIG}(100 \mathrm{mg} / \mathrm{kg})+\mathrm{CBZ}$ $(100 \mathrm{mg} / \mathrm{kg})$ and the VIG $(200 \mathrm{mg} / \mathrm{kg})+\mathrm{CBZ}$ $(200 \mathrm{mg} / \mathrm{kg})$ combination treatments significantly $(\mathrm{p}<0.05)$ decreased the testosterone in male Wistar rats and this effects were not reverted despite 8 weeks of drug withdrawal (Figure 3).

VIG (200mg/kg), CBZ (200mg/kg), VIG $(100 \mathrm{mg} / \mathrm{kg})+\mathrm{CBZ}(100 \mathrm{mg} / \mathrm{kg})$ or $\mathrm{VIG}$ $(200 \mathrm{mg} / \mathrm{kg})+\mathrm{CBZ}(200 \mathrm{mg} / \mathrm{kg})$ combination treatments had no significant $(\mathrm{p}<0.05)$ difference on the serum luteinizing hormone concentration. However, withdrawal of the treatments brought about a significant $(\mathrm{p}<0.05)$ decrease in the concentration of luteinizing hormone compared with their control counterpart (Figure 4).

VIG $(200 \mathrm{mg} / \mathrm{kg})$ significantly $(\mathrm{p}<0.05)$ decreased the FSH concentration while CBZ $(200 \mathrm{mg} / \mathrm{kg}), \quad \mathrm{VIG}(100 \mathrm{mg} / \mathrm{kg})+\mathrm{CBZ}$ $(100 \mathrm{mg} / \mathrm{kg})$ and VIG $(200 \mathrm{mg} / \mathrm{kg})+\mathrm{CBZ}$ $(200 \mathrm{mg} / \mathrm{kg})$ significantly $(\mathrm{p}<0.05)$ increased the serum FSH concentration. However, despite the drug withdrawal, there was still a significant $(p<0.05)$ increase $(p<0.05)$ in the serum FSH concentration of VIG $(200 \mathrm{mg} / \mathrm{kg})$ and CBZ $(200 \mathrm{mg} / \mathrm{kg})$ treated groups compared to their control (Figure 6).

VIG (200mg/kg), CBZ (200mg/kg) VIG $(100 \mathrm{mg} / \mathrm{kg})+\mathrm{CBZ}(100 \mathrm{mg} / \mathrm{kg})$ and VIG $(200 \mathrm{mg} / \mathrm{kg})+\mathrm{CBZ}(200 \mathrm{mg} / \mathrm{kg})$ significantly $(p<0.05)$ decreased the sperm count, motility, viability and normal morphology compared to the control. (Table 2).

Figure $7 \mathrm{a}$ and $\mathrm{b}$ showed the histomorphology of the testes of rats treated with VIG $(200 \mathrm{mg} / \mathrm{kg}), \quad \mathrm{CBZ} \quad(200 \mathrm{mg} / \mathrm{kg}), \quad \mathrm{VIG}$ $(100 \mathrm{mg} / \mathrm{kg})+\mathrm{CBZ}(100 \mathrm{mg} / \mathrm{kg})$ and $\mathrm{VIG}$ 
$(200 \mathrm{mg} / \mathrm{kg})+$ CBZ $(200 \mathrm{mg} / \mathrm{kg})$ combination treated rats revealed signs of vacuolation in the interstitial cell (IC) compared to the control except the VIG $(100 \mathrm{mg} / \mathrm{kg})+\mathrm{CBZ}(100 \mathrm{mg} / \mathrm{kg})$ treated. Degenerating features earlier noticed were reverted consequent upon drug withdrawal except the vacuolated interstitial cells in the VIG $(100 \mathrm{mg} / \mathrm{kg})+\mathrm{CBZ}(100 \mathrm{mg} / \mathrm{kg})$ combination treated rats' testicles.

\section{DISCUSSION}

The study assessed the effects of 8 weeks treatment and another 8 weeks of drug withdrawal of the conventional antiepileptic drug CBZ, newer antiepileptic drug VIG or the combination of the two on the hypothalamicpituitary-testicular axis. Bearing in mind that these two antiepileptics are centrally acting drugs, this therefore suggests that these drugs either alone or in combination might have interacted with the ventrolateral hypothalamus (VLH).lesion to this part of hypothalamus induces anorexic condition that might have resulted in animals failure to feeding, wasting of muscle and ultimately loss in body weight. This finding is in line with the previous reports that vigabatrin administration is associated with weight reduction through its anorexic (21). CBZ chronic treatment has also been reported in the earlier study to inhibit weight gain (21). The findings of this report imply that administration of antiepileptic drugs (AEDs) used in this study have the ability to inhibit hypothalamic neurons associated with the regulation of food consumption and energy expenditure thereby leading to loss of appetite. Consequently, there was a decrease in body weight gain throughout the course of the study since body weight gain or loss depends on the balance between food consumption/calorie intake and energy expenditure. The brain integrates information from many afferent inputs and circulating factors to regulate food intake and energy expenditure. The significant decrease in body weight of rats during the periods of drug administration and recovery can also be attributed to an alteration in caloric balance and lesions of the ventromedial nuclei of the hypothalamus (Satiety centre) and the ventrolateral hypothalamic nuclei (Feeding centre) producing a syndrome of aphagia and weight loss in the experimental animals as an indication of the effects of the drugs on these centers (22). This is in contrary to previous studies which reported that administration of AEDs increased the level of Cortisol, leptin and neuropeptide $Y^{\prime \prime}(21,22,23)$.
This suggests that VIG treatment and combination therapy of CBZ/ VIG $(200 \mathrm{mg} / \mathrm{kg})$ are associated with significant increase in relative testicular weights in rats. This effect was observed in the relative epididymal weights of these rats. This is contrary to the findings of Daoud et al. (15) who reported significant decrease in relative testicular and epididymal weights in rats treated with VIG. The effects of antiepileptic drugs on the reproductive function could be attributed to their central effects on hypothalamic-pituitary-gonad axis. Most of antiepileptic drugs act as GABA-agonists. The GABA -ergic system is the predominant inhibitory system in the mammalian central nervous system. GABA nerve fibers showed high density in the hypothalamus, posterior and intermediate lobes of pituitary (23). Administration of carbamazepine (4 to 52 weeks at dosage levels of $50-400 \mathrm{mg} / \mathrm{kg} /$ day) has been reported to be associated with testicular atrophy (11). The restoration of these parameters towards control values after the recovery period suggests that vigabatrin and carbamazepine treatment have reversible deleterious effects (11).

The fact that sperm count gives the cumulative result of all stages in sperm production makes it one of the most reliable sensitive tests for spermatogenesis (24). It is one of the most sensitive tests for spermatogenesis and highly correlated with fertility (25). In rats, spermatogenesis takes place within a period of 50 and 60 days (26). This study suggests that spermatogonia cells were vulnerable to the toxic effects of VIG, CBZ and their combination. Chemicals which interfere with the spermatogonial (earliest) phase of cell multiplication may have a disproportionately greater effect on sperm output than those that exert their effects at the spermatid phase since the spermatogonial phase is when almost all cell multiplication occurs (27). This was, however, buttressed with the fact that the study recorded a significant decrease in the total number of abnormal sperm cells (in the experimental groups) at the end of the study when compared with the control group.

The decline in sperm motility could have been due to an assault to the histoarchitecture of the seminal vesicles with a corresponding functional decline in fructose-producing abilities. Another possible explanation for the significant decline in sperm motility of the rats that received drug could be as a result of the ability of the drugs to pass through the bloodtestis barrier. Raji and co-workers (20) reported 
that a significant decline in sperm motility following the administration of a chemical agent could be associated with the ability of the agent to permeate the blood-testis barrier and thus, create a different microenvironment in the inner aspects of the seminiferous tubules when compared with its outer parts (20).

Decline in serum testosterone levels observed during the period of drug administration suggests a possible deleterious effect of administration of VIG, CBZ and or its combination on the secretory function of testicular androgen. The biosynthesis of androgens by the Leydig cells and the production of spermatozoa in the epithelium of seminiferous tubules are two independent but synchronized functions that controls overall testicular function (27). Male libido, spermatogenesis as well as growth and development of male reproductive organs are controlled by androgens (testosterone and androsterone), particularly testosterone in association with follicle stimulating hormone (FSH) (28).

Despite the significant (CBZ only) and increase in serum FSH levels and an apparently uninterrupted secretion of LH that were recorded after 8 weeks drug treatment, there was a decrease in the amounts of serum testosterone in the experimental groups when compared with the control group. This suggests that the decreases in serum testosterone that were recorded during the period of administration of vigabatrin, carbamazepine and their combinations were structural in origin. It could have resulted from inability of the Leydig cells in the testes to respond to available serum LH due to histological distortions. This explains the secondary manifestations of significant reductions in sperm characterization that were recorded in this study during the period of drug administration, since testosterone is responsible for the sequence of the remaining stages of spermatogenesis after proliferation of spermatogonia by FSH. While $\mathrm{FSH}$ is responsible for the initiation of spermatogenesis, testosterone is responsible for the maintenance of spermatogenesis $(28,29)$. Luteinizing hormone (LH) is, however, essential for the secretion of testosterone from Leydig cells (30). These reproductive hormones are biologically connected such that alteration(s) in one factor may elicit deleterious disturbance(s) in reproductive functions. Although, the study recorded a restoration in the sperm characteristics (sperm count, motility, viability and morphology) of rats after 8 weeks recovery period when compared to the control group, the significant decrease in serum testosterone levels that was induced was found to be irreversible.

\section{CONCLUSION}

Long-term treatment with VIG, CBZ or its combination produced a pathophysiological derangement in the hormonal profile of pituitarygonadal axis and morphological integrity of the testis. This is evident that administration of these drug(s) induces a reversible impairment to the reproductive hormones and sperm profiles. It is possible that the active reversal of sperm characteristics that was observed was due to the elimination of the drugs from the animals after 8weeks of administration. However, these factors seemed insufficient to attenuate alterations in serum testosterone levels. This is subject to further studies.

Conflict of interest: The author declares no conflict of interest.

\section{REFERENCES}

1) Brodie, M.J., Elder A.T and Kwan P (2009) Epilepsy in later life. Lancet Neurology. 8:1019-1030.

2) Thurman, D. J., Beghi, E., Begley, C. E., Berg, A T., Buchhalter, J. R., Ding, D., Hesdorffer, D. C., Hauser, W. A., Kazis, L., Kobau, R., Kroner, B., Labiner, D., Liow, K., Logroscino, G., Medina, M. T., Newton, C. R., Parko, K., Paschal, A., Preux, P. M., Sander, J. W., Selassie, A., Theodore, W., Tomson, T., Wiebe, S. and ILAE Commission on, Epidemiology (2011)."Standards for epidemiologic studies and surveillance of epilepsy." Epilepsia. 52 (7): 226232.

3) Eadie, M. J. (2012). "Shortcomings in the current treatment of epilepsy." Experimental Review of Neurotherapeutics12 (12):1419-1427.

4) Devlin, A., Odell, M., Charlton, J. and Koppel, S. (2012). "Epilepsy and driving: current status of research." Epilepsy research.102 (3): 135-152.

5) Brodie M.J., Elder A.T and Kwan P (2009). Epilepsy in later life. Lancet Neurology. 8:1019-1030.

6) Camfield P and Camfield C (2015). Incidence, prevalence and aetiology of seizures and epilepsy in children Epileptic Disorder 17 (2): 117-123.

7) Sander, J.W. (2004). The use of Antiepileptic Drugs - Principles and Practice. Epilepsia 45 (6): $1817-1829$.

8) Kwan, P. and Brodie, M.J. (2006). Combination therapy in epilepsy: when and what to use. Drugs. 66 (14): $1817-1829$.

9) Brodie, M.J. and Sills, G.J. (2011). Combining antiepileptic drugs - Rational Polytherapy. Seizure 20 (5): 369-375

10) Dana-Haeri, J., Oxley, J and Richens, A. (1982). Reduction of free testosterone by antiepileptic 
drugs. British Medical Journal284: 85-86.

11) Osuntokun, O.S, Olayiwola, G, Oladele A., Ola Iand AyokaAbiodun $\mathrm{O}(2017)$. Pathophysiology $24(2): 63-69$.

12) Artama, M., Isojarvi, J. I. and Auvinen, A. (2006). Antiepileptic drug use and birth rate in patients with epilepsy--a population-based cohort study in Finland. Human Reproduction. 21(9): 2290-2293.

13) Shetty, A.J. and Narayana, K. (2007). The effect of carbamazepine on sperm morphology in Wistar rats. Indian Journal of Physiology and Pharmacology 51 (3): 255-260.

14) Sanchez-Alcaraz, A., Quintana, M.B., Lopez, E., Rodriguez, I and Llopis, P. (2002): Effect of vigabatrin on the pharmacokinetics of carbamazepine. Journal of clinical pharmacy and therapeutics 27 (6): 427 - 430 .

15) Daoud A. S., Bataineh H., Otoom S. and AbdulZahra E. (2004). The effect of Vigabatrin, Lamotrigine and Gabapentin on the fertility, weights, sex hormones and biochemical profiles of male rats. Neuroendocrinology Letters 25(5):351-5.

16) Olaibi, K. O., Osuntokun, O. S. and Omamuyovwi, M. I. (2014). Effects of chronic administration of gabapentin and carbamazepine on the histomorphology of the hippocampus and striatum. Annals of neuroscience. 21(2): 57-61.

17) Raji, Y., Ifabunmi, S. O., Akinsomisoye, O. S., Morakinyo, A. O. and Oloyo, A. K. (2005a). Gonadal responses to antipsychotic drugs; Chlorpromazine and Thioridazine reversibly suppress testicular functions in albino rats. International Journal of Pharmacology. 1 (3): 287-292.

18) Otoom, S., Batieneh, H., Hassan $Z$ and Daoud A (2004). Effects of long- term use of Topiramate on fertility and growth parameter in adult Male Rats. Neuroendocrinology Letters 5 (25): 351355.

19) Maree, L., du-Plessis, S.S., Menkveld, R and van- der- Horst G (2010). Morphometric dimensions of the human sperm head depend on the staining method used. Human Reproduction 25 (6): 1369-1382.

20) Raji, Y., Udoh, U. S., Mowoyeka, O. O., Ononye, F. C. and Bolarinwa A. F. (2003). Implication of endocrine malfunction in male antifertility efficacy of Azadirachtaindica xtract in rats. African Journal of Medicine and Medical Science.32:159-165

21) Bito, V (2003). Effect of antiepileptic drugs on body weight. CNS drugs 17 (11): 781-791.

22) Aydin, K., Serdaroglu, A. and Okuyaz, C. (2005). Serum insulin, leptin, and neuropeptide Y levels in epileptic children treated with valproate. Journal of Child Neurology. 20 (3): 848-851.

23) Sheth, R. D. and Montouris, G. (2008). Metabolic effects of AEDs: impact on body weight, lipids and glucose metabolism. International Review of Neurobiology. 83: 329-
346.

24) Laxminarayana, B., Vijary, P. and Yeshwanth, R. (2010). Reproductive toxicity of sodium valproate in male rats. Indian Journal of pharmacology. 42 (2): 90 - 94

25) Meistrich, M. L. (1982). Quantitative correlation between testicular stem cell survival, sperm production and fertility in the mouse after treatment with different cytotoxic agents. Journal of Andrology. 3: 58-68.

26) Afaf, A. E. (2009). Influence of subchronic exposure of lead on biochemical markers and microelements in testicular tissue of rats. Nature and Science. 7 (2): 0740 -1545.

27) Da-Nian, Q. I. N. and Mary, A. L. (2001). Effect of testicular capsulotomy on fertility of rats. Asian Journal of Andrology. 3: 21 - 25.

28) Sharpe, R. M. (1994). Regulation of spermatogenesis. In. Knobil, E, Neil, J. D. The physiology of reproductive Raven Press, New York. Pp. 1363-1434

29) Vomberger, W., Prins, G., Musto, N. A. and Suarez- Quian, C. A. (1994). Andrology receptor distribution in the rat testis: New implications for androgen regulation of spermatogenesis. Endocrinology. 134: 2307-2316.

30) Ballester, J. M., Munoz, M. C., Dominguez, J., Rigau, T., Guinovart, J. J., Rodriguez-Gil, J. E. (2004).Insulin-dependent diabetes affects testicular functions by FSH and LH-linked mechanisns. Journal of Andrology. 25: 706-719. 
Table1: Effects of vigabatrin, carbamazepine or its combination on the body weight of maleWistar rats

\begin{tabular}{llll}
\hline Groups & Initial body weight $(\mathrm{g})$ & Final body weight $(\mathrm{g})$ & Percentage weight gain $(\%)$ \\
\hline Control & $170.00 \pm 0.15$ & $236.40 \pm 0.17$ & $28.09 \pm 4.57$ \\
& & $(272.00 \pm 0.21)$ & $(13.09 \pm 2.57)$ \\
VIG $(200 \mathrm{mg} / \mathrm{kg})$ & $172.00 \pm 0.18$ & $183.80 \pm 0.13^{?}$ & $6.42 \pm 0.89^{\alpha}$ \\
& & $\left(218.80 \pm 0.22^{?}\right)$ & $\left(16.00 \pm 3.60^{*}\right)$ \\
$\mathrm{CBZ}(200 \mathrm{mg} / \mathrm{kg})$ & $168.20 \pm 0.16$ & $217.70 \pm 0.18^{?}$ & $22.74 \pm 3.68^{?}$ \\
& & $\left(244.70 \pm 0.24^{?}\right)$ & $\left(11.03 \pm 2.48^{?}\right)$ \\
VIG $(100 \mathrm{mg} / \mathrm{kg})+\mathrm{CBZ}(100 \mathrm{mg} / \mathrm{kg})$ & $175.40 \pm 0.20$ & $203.33 \pm 0.17^{?}$ & $13.73 \pm 2.39^{?}$ \\
& & $\left(216.30 \pm 0.19^{?}\right)$ & $\left(6.00 \pm 0.77^{?}\right)$ \\
VIG $(200 \mathrm{mg} / \mathrm{kg})+\mathrm{CBZ}(200 \mathrm{mg} / \mathrm{kg})$ & $168.40 \pm 0.02$ & $208.00 \pm 0.21^{?}$ & $19.04 \pm 1.05^{?}$ \\
& & $\left(239.00 \pm 0.24^{?}\right)$ & $(12.97 \pm 3.05)$ \\
\hline
\end{tabular}

Data are presented as Mean $\pm \operatorname{SEM}(n=5)$;

${ }^{\alpha}$ significant decrease $(p<0.05)$ compared to the control group.

* significant increase at $p(<0.05)$ compared to the control group.

Values presented in parenthesis show recovery experiment value

Table 2: The effects of vigabatrin, carbamazepine or its combination on sperm indices in male Wistar rat

\begin{tabular}{lllll}
\hline Treatment Group & $\begin{array}{l}\text { Sperm Count } \\
\left(10^{6} / \mathrm{ml}\right)\end{array}$ & \% Motility & $\begin{array}{l}\text { \% } \\
\text { Morphology }\end{array}$ & \% Viability \\
\hline Control & $130.4 \pm 0.5$ & $91.6 \pm 0.4$ & $15.2 \pm 0.7^{?}$ & $98.0 \pm 0.32$ \\
& $(132.0 \pm 0.5)$ & $(86.6 \pm 0.7)$ & $(15.0 \pm 0.9)$ & $(95.4 \pm 0.2)$ \\
VIG $(200 \mathrm{mg} / \mathrm{kg})$ & $117.6 \pm 0.9^{?}$ & $77.6 \pm 0.5^{?}$ & $11.6 \pm 0.4^{?}$ & $97.0 \pm 0.3^{?}$ \\
& $(118.0 \pm 0.8)^{?}$ & $(82.2 \pm 0.4)^{?}$ & $(13.2 \pm 04)^{?}$ & $(93.0 \pm 0.3)^{?}$ \\
CBZ $(200 \mathrm{mg} / \mathrm{kg})$ & $105.0 \pm 0.9^{?}$ & $75.2 \pm 0.7^{?}$ & $12.0 \pm 0.3^{?}$ & $97.2 \pm 0.5^{?}$ \\
& $(102.0 \pm 0.4)^{?}$ & $(76.6 \pm 0.5)^{?}$ & $(14.0 \pm 0.4)$ & $(95.4 \pm 0.4)$ \\
VIG $(100 \mathrm{mg} / \mathrm{kg})+\mathrm{CBZ}(100 \mathrm{mg} / \mathrm{kg})$ & $102.8 \pm 0.9^{?}$ & $72.0 \pm 1.6^{?}$ & $13.4 \pm 0.7^{?}$ & $966 \pm 0.3^{?}$ \\
& $(102.0 \pm 0,4)^{?}$ & $(85.0 \pm 0.3)$ & $(14.8 \pm 0.4)$ & $(95.6 \pm 0.5)$ \\
VIG $(200 \mathrm{mg} / \mathrm{kg})+\mathrm{CBZ}(200 \mathrm{mg} / \mathrm{kg})$ & $96.0 \pm 15.4^{?}$ & $80.6 \pm 0.7^{?}$ & $9.40 \pm 0.5^{?}$ & $97.0 \pm 0.3^{?}$ \\
& $(12.6 \pm 0.7)$ & $(85.6 \pm 0.8)$ & $(14.6 \pm 0.32)$ & $(95.2 \pm 0.4)$ \\
\hline
\end{tabular}

Data are presented as Mean $\pm \operatorname{SEM}(n=5)$;

significant decrease $(p<0.05)$ compared to the control group

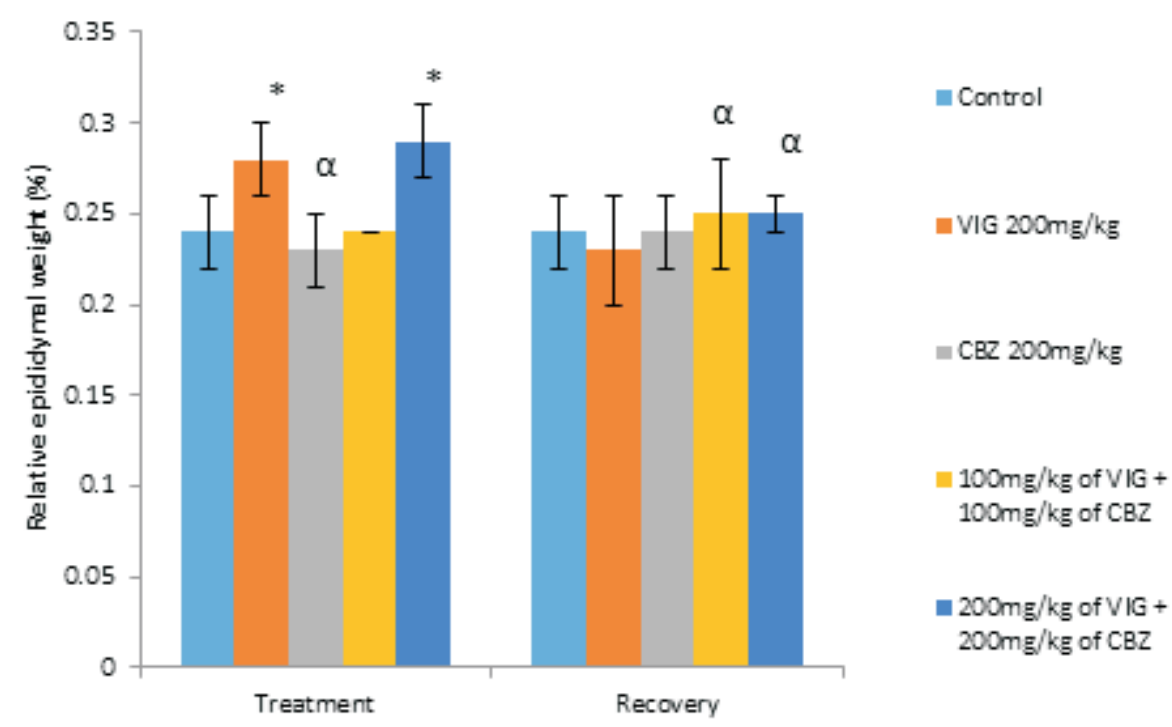

Data are presented as Mean $\pm \operatorname{SEM}(n=5)$;

${ }^{\alpha}$ significant decrease $(p<0.05)$ compared to the control group.

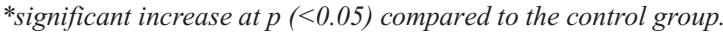

Figure 1: Effects of vigabatrin, carbamazepine or its combination on relative epididymal weight of treated Wistar rats 


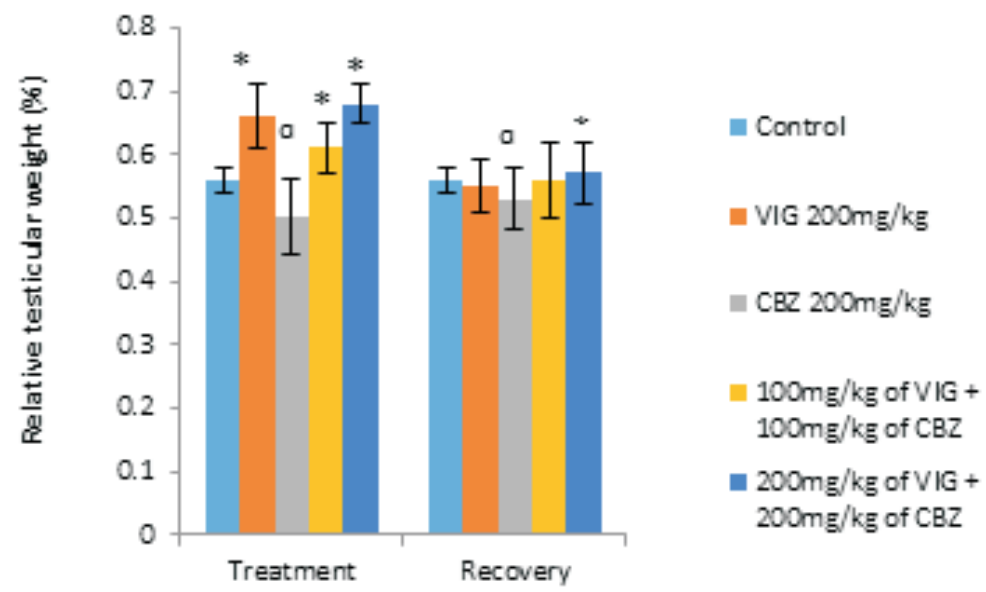

Data are presented as Mean $\pm \operatorname{SEM}(n=5)$;

${ }^{\alpha}$ significant decrease $(p<0.05)$ compared to the control group.

*significant increase at $p(<0.05)$ compared to the control group.

Figure 2: Effects of vigabatrin, carbamazepine or its combination on relative testicular weight of Wistar rats.

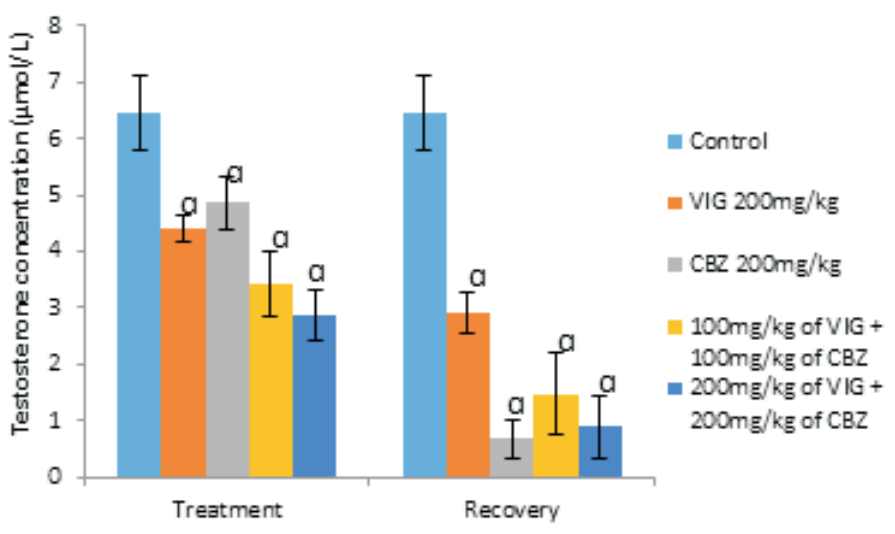

Data are presented as Mean \pm SEM $(n=5)$

${ }^{a}$ significant decrease $(p<0.05)$ compared to the control.

Figure 3: Effects of vigabatrin, carbamazepine or its combination on serum testosterone concentration in male Wistar rats

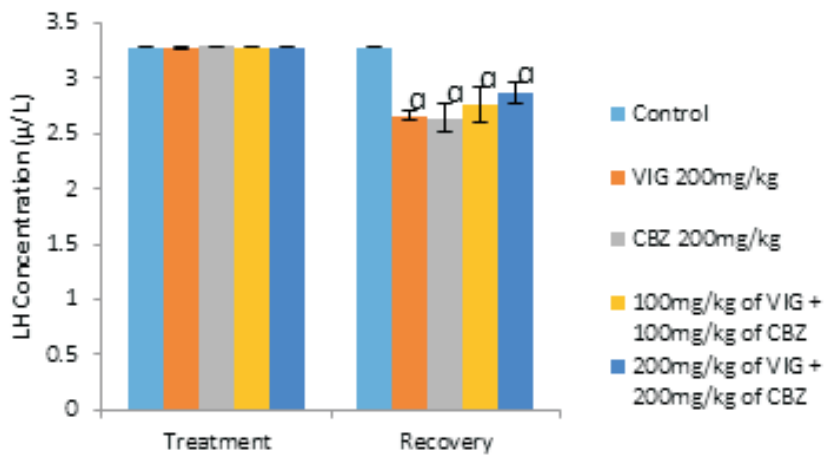

Data are presented as Mean $\pm \operatorname{SEM}(\mathrm{n}=5)$

${ }^{?}$ Significant decrease at $(\mathrm{p}<0.05)$ compared to the control

Figure 4: Effects of vigabatrin, carbamazepine or its combination on serum luteinizing hormone concentration in male Wistar rats. 


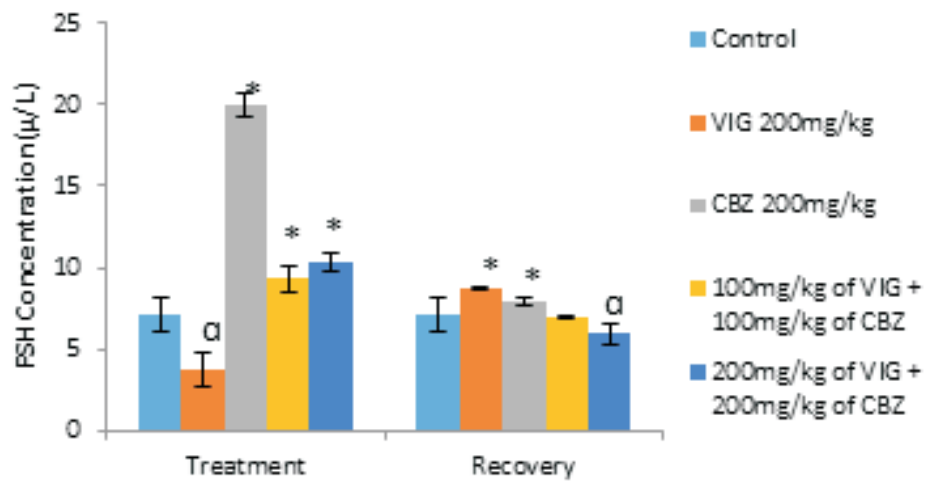

Data are presented as Mean $\pm \operatorname{SEM}(n=5)$;

${ }^{\alpha}$ significant decrease $(p<0.05)$ compared to the control group.

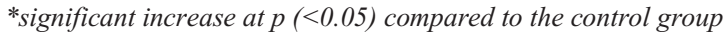

Figure 5: Effects of vigabatrin, carbamazepine or its combination on serum follicle stimulating hormone concentration in male Wistar rats
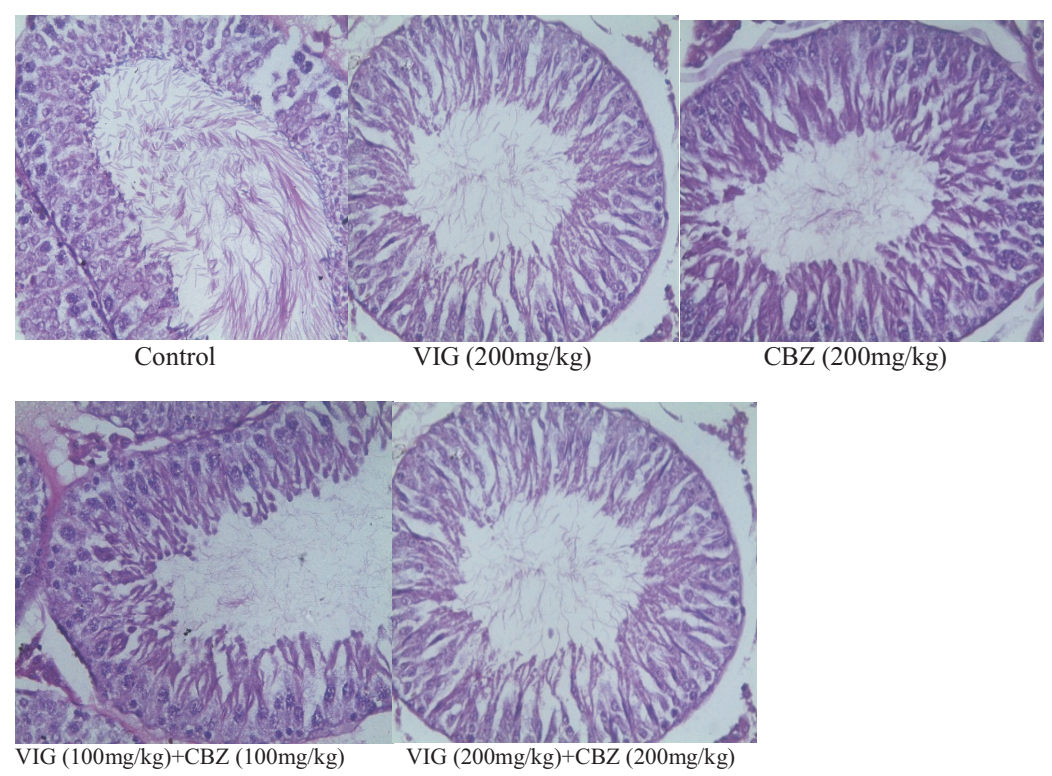

Figure 7a: Histomorphology of the testes after 8 weeks administration of VIG, CBZ and VIG-CBZ combination

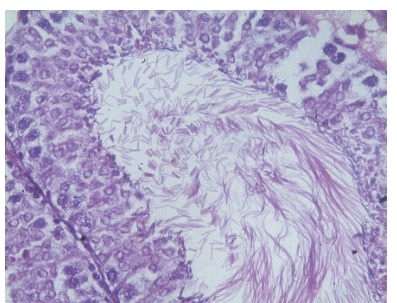

Control

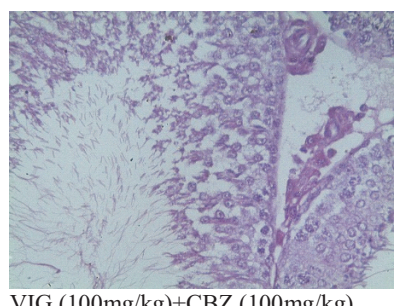

VIG $(100 \mathrm{mg} / \mathrm{kg})+\mathrm{CBZ}(100 \mathrm{mg} / \mathrm{kg})$

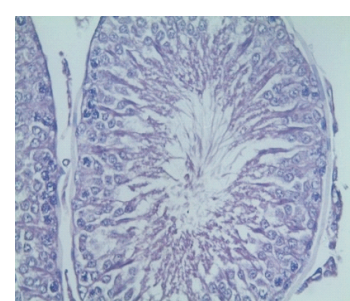

VIG $(200 \mathrm{mg} / \mathrm{kg})$

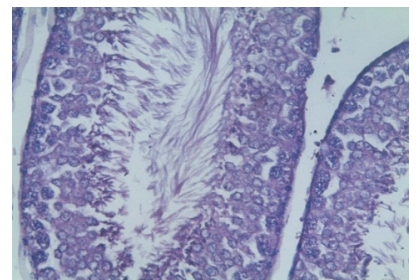

VIG $(200 \mathrm{mg} / \mathrm{kg})+\mathrm{CBZ}(200 \mathrm{mg} / \mathrm{kg})$

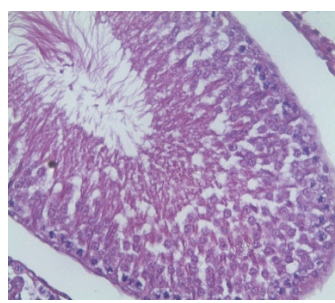

CBZ $(200 \mathrm{mg} / \mathrm{kg})$

Figure 7b: Histomorphology of the testes after 8 weeks of VIG, CBZ and VIG-CBZ combination drug withdrawal

Res. J. of Health Sci. Vol 5(4), Oct./Dec., 2017 